\title{
Analysis of the Genetic Component of Coronary Artery Disease
}

\author{
Antonio de Padua Mansur
}

São Paulo, SP - Brazil

The genetic component of atherosclerotic disease has been increasingly investigated, and some genetic characteristics have been associated with that disease. The methodology and interpretation of the results of the genetic studies, however, have been frequently questioned. This review article discusses these points and suggests methods of analysis that may improve the understanding of the pathogenesis of coronary artery disease of atherosclerotic origin.

General considerations - Coronary artery disease is the major cause of morbidity and mortality in the most developed regions of Brazil. Despite its high prevalence, the progressive reduction in mortality in the majority of Brazilian regions has been notable in recent years. The reasons are varied, but it is currently agreed that this reduction is primarily due to the increasing improvement in socioeconomic conditions, with special attention to the control of risk factors for cardiovascular diseases. Better understanding of the pathophysiology of coronary artery disease has also allowed advances in the pharmacological and surgical treatments for that entity and in the nonsurgical techniques of coronary reperfusion. Control of risk factors, however, continues to be the most effective management in regard to primary and secondary prevention of coronary artery disease.

The major risk factors for coronary artery disease are: tobacco use, hypercholesterolemia, systemic hypertension, and diabetes mellitus. Other factors, such as high levels of lipoprotein(a), triglycerides, and fibrinogen, have been considered independent risk factors too ${ }^{1}$. The intensity of participation of these risk factors in the development of coronary artery disease depends on the environmental components and on the genetic characteristics of each individual or of one population.

The presence of a family history is another important risk factor for coronary artery disease. Familial antecedents depend on genetic characteristics, as do other known factors, such as hypertension, dyslipidemia, and diabetes mellitus, which influence the development of coronary atherosclerosis. Currently, the genetic characteristics described and directly related to the atherogenic and thrombogenic

Instituto do Coração do Hospital das Clínicas - FMUSP

Mailing address: Antonio de Padua Mansur - Incor - Unidade de Coronariopatias Crônicas - Av. Dr. Enéas C. Aguiar, 44 - 05403-000 - São Paulo, SP, Brazil processes are innumerable. Even though several genes influence both processes, some genes, such as those encoding the angiotensin-converting enzyme ${ }^{2,3}$, angiotensinogen $^{4,5}$, AT1 angiotensin receptor ${ }^{6}$, and that of the apolipoproteins $\mathrm{AI}, \mathrm{B}$, and $\mathrm{E}^{7-10}$, apparently have a more prominent participation in the atherogenic process. On the other hand, prothrombin ${ }^{11}$, platelet glycoprotein IIb/IIIa ${ }^{12}$, and fibrinogen ${ }^{13}$ polymorphisms are mainly involved in the thrombogenic process.

Genetic component - The participation of the genetic component in the population with coronary artery disease is unknown. In clinical practice, investigation of the probable hereditary component influencing the development of atherosclerosis is basically performed through the verification of the presence of precocious coronary artery disease in parents, i. e., diagnosis of coronary artery disease in the father before the age of 55 years and in the mother before the age of 65 years, or in the siblings. This analysis, even though significant, has little sensitivity and does not consider the existence, isolated or in association, of other potential risk factors in these patients, which may significantly influence the development of an ischemic coronary process or even a peripheral thromboembolic episode. One of the classic examples is the adverse effect of tobacco potentiated by the use of contraceptives. This predisposition to thromboembolic events is associated with disorders in the coagulation system, such as elevated serum levels of fibrinogen (due to tobacco) or reduced serum levels of vitamin C (genetically transmitted). In the same way, the influence of the polymorphism of the genes responsible for the coagulation factors in this interaction is discussed. Therefore, investigators have begun to analyze the association of genetic polymorphisms with coronary artery disease.

Interpretation of the genetic studies-Due to the complexity of the atherosclerotic process, the genes initially studied were those strongly related to the major risk factors of coronary artery disease, especially systemic hypertension and dyslipidemias. The first polymorphism related to coronary artery disease was that of apolipoprotein $\mathrm{E}$, which accounts for significant changes in the lipid profile ${ }^{14}$. Then, the polymorphism of the angiotensin-converting enzyme was related to acute myocardial infarction, and this association was studied because it was formerly known that the different genotypes expressed different activities of the angiotensinconverting enzyme, i. e., higher or lower levels of angiotensin II influencing vascular tonus and blood pressure ${ }^{15}$. 
However, studies of genetic polymorphisms in the population with coronary artery disease show conflicting results ${ }^{16-18}$. In the same way, polymorphisms of the coagulation factors, which theoretically would take a significant part in the thrombogenic process in young patients with coronary artery disease also show conflicting results ${ }^{19}$. This controversy may be related to inappropriate methodological studies, and the major criticisms are the reduced number of patients and the absence of a panel of polymorphisms ${ }^{20}$. The rule has been the analysis of isolated polymorphisms ${ }^{21}$ and, in many studies, absence of a multivariable analysis defining genetic markers that independently contribute to the development of coronary artery disease ${ }^{22}$. To avoid studies with a reduced number of patients and statistical errors of the beta type (test power $<0.80$ ), participation of several research centers is fundamental. This is possible because of the existence of several centers with high scientific standards in many regions of Brazil. The multicenter characteristic favors not only the increase in the size of the population studied but also avoids isolated analyses of populations that may not be in the equilibrium of Hardy-Weinberg. In reality, the Brazilian population, due to its multiracial ethnic characteristics, is ideal for genetic studies ${ }^{23,24}$.

Models for genetic studies - The progressive increase in knowledge in the field of molecular biology has questioned how this revolution can influence public health progra$\mathrm{ms}$ or how to improve the prognostic value of the genetic analysis in the development and progression of atherosclerotic disease, which is known to be multifactorial. Analysis of these genetic characteristics and their interrelation with environmental factors may precociously identify highrisk individuals or families for cardiovascular diseases. This identification may even facilitate the degree of response to certain proposed therapeutics. In a realistic manner, however, the model for genetic evaluation of a more complex and polygenic multifactorial disease requires analysis of a panel of genetic polymorphisms and their interrelation with the main risk factors for atherosclerosis ${ }^{25}$. In the same way, strategies of analysis, such as the sib-pair models (analysis of pairs in siblings), the relative-pair model (analysis of pairs in relatives), etc, are being increasingly used as forms to improve the detection of polymorphisms responsible for coronary artery disease through comparison of the DNA of affected and healthy individuals in the same family. Among them, the sib-pair model, which is a comparison of siblings with coronary artery disease with unaffected siblings, is considered one of the best techniques for providing an increase in sensitivity of the genetic analysis for diseases of multifactorial characteristics, such as atherosclerosis ${ }^{26,27}$. The advantage of this analysis is that the genetic characteristics of the analyzed pair (an affected and a healthy sibling) are uniform and, therefore, differences in the genome accounting for coronary artery disease may be easier to identify. This way, analysis of several genes may establish for the first time criteria or a genetic profile more specifically associated with coronary artery disease and, consequently, defining more conclusive criteria for primary and secondary preventions, which constitute state-of-the-art measures for reducing cardiovascular events.

\section{Conclusion}

Association of one or more genetic polymorphisms with atherosclerosis should be based on studies with an appropriate number of patients and methodology. The polymorphisms analyzed should have a biological meaning, and their genetic products should have a physiological activity strongly related to the major risk factors, mainly hypercholesterolemia, hypertension, and diabetes mellitus, or to the atherogenic or thrombogenic processes. Similarly, the use of strategies for analysis, such as analysis of pairs in siblings or relatives, and a panel of polymorphisms improve identification of genetic polymorphisms associated with atherosclerotic disease.

\section{References}

1. Pyörälä K, Backer G, Graham I, Poole-Wilson P, Wood D. Prevention of coronary heart disease in clinical practice. Recommendations of the Task Force of the European Society of Cardiology, European Atherosclerosis Society and European Society of Hypertension. Eur Heart J 1994; 15: 1300-31.

2. Cambien F, Poirier O, Lecerf L, et al. Deletion polymorphism in the gene for angiotensin-converting enzyme is a potent risk factor for myocardial infarction. Nature 1992; 359: 641-4.

3. Arbustini E, Grasso M, Fasani R, et al. Angiotensin converting enzyme gene deletion allele is independently and strongly associated with coronary atherosclerosis and myocardial infarction. Br Heart J 1995; 74: 584-91.

4. Ishigami $\mathrm{T}$, Umemura $\mathrm{S}$, Iwamoto $\mathrm{T}$, et al. Molecular variant of angiotensinogen gene is associated with coronary atherosclerosis. Circulation 1995; 91: 951-4.

5. Katsuya T, Koike G, Yee TW, et al. Association of angiotensinogen gene T235 variant with increased risk of coronary heart disease. Lancet 1995; 345: 1600-3.

6. Alvarez R, Reguero JR, Batalla A, et al. Angiotensin-converting enzyme and angiotensin II receptor 1 polymorphisms: association with early coronary disease. Cardiovasc Res 1998; 40: 375-9.

7. Humphries SE. DNA polymorphisms of the apolipoprotein genes - their use in the investigation of the genetic component of hyperlipidaemia and atherosclerosis. Atherosclerosis 1988; 72: 89-108.

8. Lusis AJ. Genetic factors affecting blood lipoproteins: the candidate gene approach. J Lipid Res 1988; 29: 297-329.

9. Novak EM, Bydlowski SP. Biologia molecular das dislipidemias. Variação genética das apolipoproteínas. Arq Bras Cardiol 1996; 67: 411-7.

10. Wilson PW,SchaeferEJ,Larson MG,Ordovas JM. ApolipoproteinEalleles and risk of coronary disease. A meta-analysis. Arterioscler Thromb Vasc Biol 1996; 16: 1250-5.

11. Arruda VR, Siqueira LH, Chiaparini LC, et al. Prevalence of the protrhombin gene variant $20210 \mathrm{G} \rightarrow \mathrm{A}$ among patients with myocardial infarction. Cardiovasc Res 1998; 37: 42-5.

12. Weiss EJ, Bray PF, Tayback M, et al. A polymorphism of a platelet glycoprotein receptor as an inherited risk factor for coronary thrombosis. N Engl J Med 1996; 334: 1090-4.

13. Behague I, Poirier O, Nicaud V, et al. Beta fibrinogen gene polymorphisms are associated with plasma fibrinogen and coronary artery disease in patients with myocardial infaction. The ECTIM Study. Etude Cas-Temoins sur l'Infarctus du Myocarde. Circulation 1996; 93: 440-9. 
14. Davignon J, Gregg RE, Sing CF. Apolipoprotein E polymorphism and atherosclerosis. Arteriosclerosis 1988; 8: 1-21.

15. Rigat B, Hubert C, Alhenc-Gelas F, Cambien F, Corvol P, Soubrier F. An insertion/ deletion polymorphism in the angiotensin I-converting enzyme gene accounting for half the variance of serum enzyme levels. J Clin Invest 1990; 86: 1343-6.

16. Samani NJ, Thompson JR, O'Toole L, Channer K, Woods KL. A meta-analysis of the association of the deletion allele of the angiotensin-converting enzyme gene with myocardial infarction. Circulation 1996; 94: 708-12.

17. Wilson PWF, Schaefer EJ, Larson MG, Ordovas JM. Apolipoprotein E alleles and risk of coronary disease. A meta-analysis. Arterioscler Thromb Vasc Biol 1996; 16: 1250-5

18. Mansur AP. Análise dos genótipos das apolipoproteínas AI, B, E, enzima conversora da angiotensina e dos fenótipos de Lewis nos pacientes com síndromes coronárias estável e instável (Tese de Doutorado). São Paulo: Universidade de São Paulo, 1998: 190p

19. Redondo M, Watzke HH, Stucki B, et al. Coagulation factors II, V, VII, and X, prothrombin gene $20210 \mathrm{G} \longrightarrow \mathrm{A}$ transition, and factor V Leiden in coronary artery disease: high factor $\mathrm{V}$ clotting activity is an independent risk factor for myocardial infarction. Arterioscler Thromb Vasc Biol 1999; 19: 1020-5.

20. Siscovick DS, Schwartz SM, Rosendaal FR, Psaty BM. Thrombosis in the yo- ung: effect of atherosclerotic risk factors on the risk of myocardial infarction associated with prothrombotic factors. Thromb Haemost 1997; 78: 7-12.

21. Mansur AP, Annicchino-Bizzacchi J, Favarato D, Avakian SD, César LAM, Ramires JAF. Angiotensin-converting enzyme and apolipoproteins genes polymorphism and different syndromes of coronary disease. Clin Cardiol (no prelo).

22. Sun GW, Shook TL, Kay GL. Inappropriate use of bivariable analysis to screen risk factors for use in multivariable analysis. J Clin Epidemiol 1996; 49: 907-16.

23. Laan M, Paabo S. Demographic history and linkage disequilibrium in human populations. Nat Genet 1997; 17: 435-8.

24. McKeigue PM. Mapping genes underlying ethnic differences in disease risk by linkage disequilibrium in recently admixed populations. Am J Hum Genet 1997; 60: $188-96$.

25. Sing CF, Zerba KE, Reilly SL. Traversing the biological complexity in the hierarchy between genome and $\mathrm{CAD}$ endpoints in the population at large. Clin Genet 1994; 46: 6-14.

26. Rotter JI, Bu X, Cantor RM, et al. Multilocus genetic determinants of LDL particle size in coronary artery disease families. Am J Hum Genet 1996; 58: 585-94.

27. Wang J, Guerra R, Cohen J. Statistically robust approaches for sib-pair linkage analysis. Ann Hum Genet 1998; 62: 349-59. 